\title{
A NAPI INGÁZÁS KÉRDÉSKÖRE A KILENCVENES ÉVEKBEN MAGYARORSZÁGON
}

(The Questions of the Commuting in the Nineties in Hungary)

\section{SZABÓ PÁL}

Ingázás. E fogalom, mint egy társadalmi jelenség megnevezése kezd halványulni a mai magyar köztudatban. Ennek talán oka, hogy a szocialista rendszerben a szó, mint számos társa - például a tanács vagy a terv - speciális tartalommal telítődött, így a rendszerváltás után a mindennapi szókincsből „,számüzetésbe küldték”. Más szavakkal megfogalmazva: a mai hétköznapi emberek többségének az ingázás a múltat jelenti, a szocializmus egyik társadalmi jelenségét. Tény, hogy a szocialista rendszer megszünésével több eleme eltünt, illetve átalakult ennek a sajátos értéktartalommal bíró életformának, azonban maga a jelenség - tudományos, statisztikai definíciójából eredően - ma is jelen van Magyarországon, ha gyakran külsőleg megváltozott formában is. A gazdaság szereplői a humán erőforrások mennyiségi, minőségi paramétereinek területi, települési eltérései esetén, az egyének pedig a más településen lévó munkahely választása révén szembesülhetnek a napi ingázás jelenségével, illetve jellemzőivel.

Ingázás. E jelenséggel több tudományterület is foglalkozik, azonban a kilencvenes évek új társadalmi, gazdasági jelenségeinek - pl. a munkanélküliség - térhódítása nemcsak a valós életben, hanem a tudományos kutatásban is bekövetkezett. A téma háttérbe szorulását fokozta még, hogy megcsappant az ingázók száma, valamint adathiány kísért. Azonban a mellözöttség nem indokolt, hiszen az ingázók relativ aránya stabil (elvileg a lakosság 25\%-át teszik ki), a jelenség újfajta ,modern" verziói, valamint a területfejlesztésben is előbukkanó kérdések aktualitását hangsúlyozzák.

\section{A napi ingázás fogalma}

A tudomány mủvelői a napi ingázást egyrészt az ideiglenes vándorlás egyik válfajának tekintik (KSH 1996, Illés 1995), időszakos migrációnak (Iván 1994), másrészt a munkaerőmozgás egyik típusának, ahol eltérő településen van a lakó- és a munkahely (Kapitány-Lakatos 1993). A tértudományban ideiglenes idejü, rövidtávú, napi periódusú áramlás (Nemes Nagy 1998). A statisztikai definíció szerint „... a naponta ingázó megjelölés az eljárók számát jelenti. .. Más településen dolgozó lakóhelyéről eljáró - az az aktív kereső, akinek a munkahelye (ahova naponta dolgozni jár), nem ugyanazon a településen van, mint a lakóhelye (ahonnan naponta dolgozni jár)." (KSH 1994, 468)

Ez a definíció széles körben elfogadott (a statisztikai gyakorlatban úgyszólván világszerte), de a kritikai észrevételek jelen vannak, melyek lényege, hogy a települé- 
sek térbeli kiterjedésének függvénye az ingázás, vagyis a kis települések esetén a bejárók rövid út esetén is ingázónak minősülnek, míg a nagykiterjedésú települések határát nagyobb távolság esetén sem lépik át a dolgozók. Ez valós, de általában Budapest két egymástól távol fekvő peremkerülete az ellenpélda, amelyek közötti napi munkaerö-áramlás nem olyan nagy volumenủ, valamint Budapest több szempontból - így népességszáma és területi kiterjedése alapján is - egyedi eset a magyar településhálózatban, emiatt külön kezelendỏ. Felvetỏdik, ha például Budapest kerületei közötti napi munkaerőmozgást is ingázásnak tekintjük (mivel minden kerület saját önkormányzattal rendelkezik, így alap is van rá), mennyiben oldódik meg a probléma. A statisztikai adatok alapján ilyen munka készült is (KapitányLakatos 1993). Tény, hogy a munkahely és a lakóhely közötti távolság, illetve az utazással eltöltött idő nem határvonal az ingázók és a nem ingázók között, de az általános kép (akár az átlag) jelentősebb eltérést mutat. Egy felmérés szerint a lakóhelyükön dolgozók 59\%-a 30 percnél kevesebbet, 23\%-a 31-60 percet, 18\%-a 61 percnél több idöt töltött el utazással, míg az ingázóknál ezek az adatok 14\%, 25\%, $61 \%$ (KSH 1989).

Kérdés, hogy érdemes-e ezt a hiányosságaival együtt elfogadott fogalmat, definíciót megbolygatni. Számomra úgy tünik, hogy nem, mert mint minden meghatározásnak, így az ingázásra adottnak is megvannak a maga buktatói, ellenpéldái. Részletesebb vizsgálatok után esetleg érdemes a fogalom módosításán gondolkodni, az EU statisztikai szabványait is figyelembe véve. Magyarországon jelenleg semmi jogi következménye nincs annak, ha valaki más településen dolgozik, mint ahol lakik, de ez - ismerve a jelenlegi magyar állapotokat - könnyen megváltozhat, $\mathrm{s}$ akkor egy piacképes mutató (ingázók száma) állhat rendelkezésünkre.

\section{A napi ingázást kialakító általános tényezök}

Az ingázás kialakulásának történeti okait vizsgálva egy kettösséget állapíthatunk meg. Egyrészt a telepúléshierarchia (város - falu) létrejötte, pontosabban a városok és a falvak térbeli elkulönülése - melynek fokozatai a társadalmi formációk változásaival és a társadalmi munkamegosztás fejlődésével szorosan összefüggnek - az okozója a jelenség kialakulásának. Sokáig a városi ipar volt a munkaerő felszívója, de az ëumúi iủuszakban egyre inkább a tercier szektor vette át ezt a szerepet, s így jelenleg is élö tényezöként van jelen az egyes országokban - gazdasági fejlettségtől függően különbözö mértékben - az ingázás kialakításában.

Másik tényezőként említendő, hogy a mezőgazdaság, áttérve korszerübb termelési módokra, jelentös munkaerö-felesleget produkált, illetve produkál, ez a tömeg nem tud a falusi lakóhelyén elhelyezkedni, s így a városban keres munkát. A falu magasabb népességszaporulata ezt a tömeget újra és újra produkálja, mely felesleg a városokban csapódik le (Böhm-Pál 1985).

Az ingázás tömegessé válásában nagy szerepet játszott a közlekedés fejlődése. A nagy kapacitású, korszerübb tömegközlekedési eszközök (például az elővárosi vas- 
utak) elterjedése, a gépjármüállomány rohamos bỏvülése mobilizálni tudta a munkaeröt. Míg az ipar (majd a tercier szektor) megteremtette a munkaerő-keresletet, a mezőgazdaság a munkaerő-kínálatot, addig a közlekedés biztosította az eltéró területeken jelentkező kereslet és kínálat közötti kapcsolat lehetőségét, az ingázás technikai feltételeit. A lakó- és munkahely fokozatosan eltávolodhatott egymástól, kialakult a településközi ingavándor-forgalom.

Az ingázás létéért egy újabb keletủ, a szuburbanizáció jelenségéhez kapcsolódó tényező is felelös. A XX. században országonként, területenként eltérő időpontokban megindult a városkörnyékek intenzív fejlödése. A nagyvárosi életforma, életkörülmények negatív jegyei (bünözés, zaj, szennyezett levegö) jelentösebb népességet taszítanak. A várost övező - régóta meglévó vagy újonnan kiépülö - nyugodtabb, egészségesebb környezetú kisebb települések alternatív lakhelyet kínálnak számukra, s általában a magasabb jövedelmü rétegek élnek is e lehetőséggel. A „kiköltözök" a lakóhelyváltás mellett a városi munkahelyet általában megtartják, s ezzel az ingázók számát gyarapítják. Magyarországon e folyamat a kilencvenes években kapott nagyobb lendületre, és jelenleg is tart (nemcsak Budapest környékén).

A munka- és lakóhelyek térbeli koncentrálódását, illetve szóródását azonban a politika is befolyásolhatja. A gazdaságpolitika (munkahelyek), a lakáspolitika (lakóhelyek), a közlekedésfejlesztés (útvonalak) és a területfejlesztés mind-mind hatással lehetnek az ingázásra (nagyságrendjére, irányára). A gazdasági szerkezet ismétlődó átalakulása egyes területeken munkahelyeket teremt, máshol megszüntet, $\mathrm{s}$ ezáltal munkaerőhiányt, illetve jelentős munkanélküliséget produkálhat. A munkahelyek számának térbeli módosulásait elvileg a lakóhelyek átcsoportosulásának kellene követnie. Ez még fejlettebb országok esetén sem valósulhat meg. A helyes területi politika a térbeli differenciák kiegyenlítésére törekszik, $\mathrm{s}$ igy nem kísérli meg a lakóhelyeket közvetett eszközökkel átcsoportosítani egy munkanélküliség sújtotta területről egy munkahelyekben bövelkedő területre, hanem megpróbálja a munkahelyteremtést a válságos területeken az egyensúly visszaállítása érdekében. Mérsékelt sikerek esetén az ingázás kedvezö közlekedési feltételeinek megteremtése által a társadalmi, gazdasági feszültség egyes területeken csökkenthető.

$\mathrm{Az}$ ingázással kapcsolatos személyes motivációk sokfélék lehetnek. Az egyéni okokat nézve két nagy csoportra oszthatók az ingázók: kényszerủ és örihéntes ingázókra. Ez a csoportositás vitatható, de véleményem szerint érdemes e két csoportot felállítani.

Kényszerú ingázónak tekinthetó az a munkavállaló, aki számára képzettségének, szakmájának megfeleló munkahely nincs a lakóhelyén, vagy van, de azt betölteni nem tudja (már betöltött az állás vagy a munkaadó nem kívánja foglalkoztatni), ezért más településre jár át dolgozni. Önkéntes ingázónak tekinthető az a munkavállaló, aki számára képzettségének, szakmájának megfelelő munkahely van a lakóhelyén, amelyet be is tölthetne, de ezt egyéni okok miatt nem kívánja megtenni, s inkább más településre jár dolgozni. Az esetek többségében a más településen megszerezhető magasabb bér a magyarázó tényező. 
A fejlettebb országokban a kényszerü ingázás kisebb arányú, mint hazánkban, mivel a magasabb bérszínvonal, a jobb anyagi körülmények lehetővé teszik a munkahelyhez történó lakóhelyválasztást. Sokan az egyéni igények alapján megválasztott lakóhelyeik révén válnak ingázóvá. Magyarországon - kifejezetten az elmaradott térségekben - a lakóhelyhez való kötöttség determinálja a munkahelyválasztást. (Az elmaradott térségekben az ingatlanárak alacsony szintje gátolja a munkaerő migrációját.) Természetesen a fejlettségtöl függetlenül minden országban megvannak azok a szakmák, szituációk, illetve azok a társadalmi rétegek, melyek kényszerü ingázásra kárhoztattak, csak az arányuk eltérö.

\section{A napi ingázók számának, arányának alakulása Magyarországon}

1960 és 1980 között az ingázók száma az aktív keresök számának növekedésével emelkedett. Ha az arányukat nézzük, akkor megállapítható, hogy jelentős változás történt, mivel míg 1960-ban körülbelül minden hetedik, addig 1980-ban már minden negyedik aktív kereső ingázott. 1980 óta azonban mind az aktív keresök, mind az ingázók száma csöḱkent, mely folyamat 1990 óta még drasztikusabban folytatódott. A csökkenés ellenére a naponta ingázók aktív keresőkön belüli aránya 1980 és 1990 között valamelyest emelkedett, és 1990 óta - mivel azonos mértékben fogyott mind az aktív keresők, mind az ingázók száma - a mutató gyakorlatilag váitozatlan maradt, 1990-ben és 1996-ban egyaránt 25\%.

Az ingázó munkaerő mennyiségi paramétereit az 1. táblázat tartalmazza.

\section{TÁBLÁZAT}

Az ingázók száma és aránya 1960-1996

(The Number and the Percentage of Commuters 1960-1996)

\begin{tabular}{|l|c|c|c|c|c|}
\hline & 1960 & 1970 & 1980 & 1990 & 1996 \\
\hline Aktív keresök száma (ezer fö) & 4760 & 4989 & 5069 & 4527 & 3492 \\
\hline Ingázók száma (ezer fö) & 636 & 977 & 1218 & 1146 & 887 \\
\hline $\begin{array}{l}\text { Ingázók aránya az aktív keresökön } \\
\text { belül (\%) }\end{array}$ & 13,4 & 19,6 & 24,0 & 25,3 & 25,4 \\
\hline
\end{tabular}

Forrás: Népszámlálási kötetek, 1960-1990. Budapest, KSH; Mikrocenzus, 1996. (1997) Budapest, KSH.

A nyolcvanas évtized végén a politikai rendszerváltással együttjáró társadalmi, gazdasági változások az ingázási állapotokra is jelentős hatással voltak.

Az ország gazdaságában jelentkező válság egyik következménye volt a nyílt 1987 után statisztikailag is regisztrált - munkanélküliség jelentkezése. A médiák hatására a közvélemény tudatában kialakult az a kép, hogy a munkanélküliség nagy számban szedte áldozatait az ingázók közül. E kép a kövełtrezö tényezókböl állt össze:

- az egyes vállalatok elsők között bocsátották el az ingázó dolgozóikat, mivel az ingázók az átlagnál alacsonyabb iskolázottságú, alacsonyabb képesítésú rétegét alkották az aktiv keresóknek, 
- a vállalatok elsỏ lépésben vidéki telephelyeiket zárták be, ahol magas volt az ingázó dolgozók száma,

- a vállalati kiadások csökkentése miatt a munkásszállásokat felszámolták,

- a távolsági utazás tarifáinak nagymérvủ emelkedése is az ingázók elbocsátását indokolta, mivel a vállalatok az utazási költségekhez való - gyakran jelentős összegü - hozzájárulásokat így meg tudták spórolni,

- a mezőgazdasági nagyizzemek felbomlása is jelentősen csőkkentette - föleg a mezőgazdasági - ingázók számát.

E tényezök alapján feltételezhetö, hogy sok ingázó dolgozó lett munkanélküli, és az ingázók száma, valamint aránya az aktív keresőkön belül jelentősen lecsökkent. Jelentős változások történhettek, de ezekrỏl hiteles elemzést nem tudunk készíteni, mivel az ingázók számáról 1990 és 1995 között adatok nem állnak rendelkezésre. A KSH 1996. évi mikrocenzusa az első olyan országos felmérés (így közvetlen adatforrás) 1990 óta, mely a napi ingázás vizsgálatát is programjába iktatta.

A felmérés kimutatta, hogy az ingázásról kialakitott képünk nem teljesen helyes, mivel igaz, hogy csökkent az ingázók száma, de arányuk nem változott. A felmérés csak a lakosság 2\%-ára terjedt ki, de országos szinten elfogadható eredményt ad. Kérdésként merül fel, hogy egyenes vonalú volt-e a mutatók, az aktív keresők és az ingázók számának csőkkenése a két idópont kőzött, vagyis az ingázók aránya végig nagyjából ugyanakkora értékkel bírt, vagy esetleg az ingázók száma gyorsabban csökkent, s így az arányértéknek kilengése volt a kilencvenes évek elején, azaz 25\% alá esett az érték.

$\mathrm{Az}$ arányérték kialakításában több tényezö is szerepet játszhatott. Az esetleges csökkenést a fentebb felsorolt tényezök indokolhatják. Kérdés, hogy a munkanélküliség tetózésével (1993) cső́kkent-e minimumra az ingázók aránya. Ez ellen az szólhat, hogy nem csak ingázók váltak munkanélkuilivé, hanem helyi lakosok is, s így már a munkanélküliség tetözése elött lecsökkenhetett minimumra az ingázók aránya. (PI. ha elsó lépésben egy gyárból elkưldték az ingázó munkaeröt, utána a gyár bezárásakor a teljes, helyi munkaerö az utcára került.) Ezentúl az is igaz, hogy a csökkenést eredményezó folyamatok idöben nem egyszerre zajlottak le az ország egyes területein. Feltehetóleg csökkent az arány, de nem lehetett nagymértékü az értékzuhanás.

Az utána bekövetkezett esetleges aránynövekedésre viszont nehéz válaszolni, itt is több tényezó játszhatott szerepet.

- Szociológiai oldalról nézve a munkaeröpiacról kivonult a nem túl mobil, alkalmazkodásra nem igazán képes munkaerő (előnyugdij, rokkantsági nyugdij), a visszamaradt aktív keresók pedig a munkakeresés során nem tekintették gátnak a telepưléshatár átlépését, leszámítva az utazási idő és költség visszatartó erejét (1996-ra az idősebb korosztály körében jelentősen csökkent 1990-hez képest az ingázók aránya).

- A lassan fejlódésnek induló gazdaságban az újonnan alakult vállalatok - közülưk föleg a külföldi érdekeltségủ, az alacsonyan kvalifikált munkaerőt je- 
lentös számban igénylö zöldmezős beruházások - foglalkoztatnak más településen éló munkaerőt is (1996-ban az ipari jellegủ nemzetgazdasági ágakra jellemzö, hogy az átlagosnál magasabb az ingázó dolgozók hányada).

- Több vállalat többször egy-egy kisebb település közigazgatási területén telepített üzemet, ahol a környezỏ nagyobb települések kvalifikált munkaerejét alkalmazhatja, akik így az ingázók számát gyarapítják.

- A már korábban megindult szuburbanizációs folyamatok felerősödtek: az egyre több nagyváros körül kialakuló és fejlödő, vonzó lakóhelyet kínáló agglomerációk a városok társadalmának magasabb státusú részét elszívják, miközben munkahelyet nem biztosítanak, így e réteg is az ingázók számát gyarapitja, ezért 1990 és 1996 között az ingázók körében megnött a kvalifikált értelmiség aránya (2. táblázat).

\section{TÁBLÁZAT}

A naponta ingázó aktív keresók megoszlása a befejezett iskolai végzettség szerint $1990,1996(\%)$

(Active Earners Commuted Daily by Highest Qualification in Percentage 1990, 1996)

\begin{tabular}{|l|c|c|c|c|c|c|}
\hline & & \multicolumn{2}{|c|}{ Általános iskola } & \multicolumn{3}{|c|}{ Befejezett } \\
\hline & $\begin{array}{c}\text { Össze- } \\
\text { sen }\end{array}$ & $\begin{array}{c}8 . \text { osztálynál } \\
\text { alacsonyabb }\end{array}$ & 8 . osztály & $\begin{array}{c}\text { középfokú } \\
\text { szakmunkás- } \\
\text { képzó iskola, } \\
\text { szakiskola }\end{array}$ & $\begin{array}{c}\text { középis- } \\
\text { kola }\end{array}$ & $\begin{array}{c}\text { felsőfokú } \\
\text { iskola }\end{array}$ \\
\hline $\begin{array}{l}\text { Naponta } \\
\text { ingázó 1990 }\end{array}$ & 100 & 6,7 & 36,3 & 30,3 & 19,7 & 7,1 \\
\hline $\begin{array}{l}\text { Naponta } \\
\text { ingázó 1996 }\end{array}$ & 100 & 1,1 & 23 & 37,8 & 27 & 11,1 \\
\hline
\end{tabular}

Forrás: Mikrocenzus 1996. (1997), Budapest, KSH.

E folyamatok időben szintén nem egyszerre zajlottak le az egész országban, $s$ így az ingázók arányát nézve a hirtelen értékugrás sem valószínü.

A két tendenciát (az ingázók számának csökkenését, illetve növekedését) okozó tényezők - területi különbségeikböl eredően - időben minél inkább átfedték egymást, annál inkább valószínü, hogy az aránygörbének nem volt túl alacsony értékü minimuma.

Az ingázás és a munkanélküliség kapcsolatáról fentebb említettük, hogy az egyes vállalatoknál elsősorban az ingázó munkaeröt építették le. Ennek következménye elvileg (hipotézis), hogy azokon a településeker, ahol az eljáró dolgozók aránya magas volt, ott később jelentős munkanélküliség alakult ki. Hipotézisként még az is megfogalmazódott, hogy a városok többségében, mint az ingázó munkaerő jelentösebb részét foglalkoztató településeken azért tudott alacsony szinten maradni a munkanélküliség, mivel a felesleges munkaerötől az ingázók elküldése révén szabadultak meg. Ha korrelációt számolunk a települések két adatsora - az eljárók aránya az aktiv népességben belul (1990) és a munkanélküliségi ráta (1993) - között, a korreláció értéke 0,008 , vagyis országosan nincs kapcsolat a két mutató között. Ha 
különbőző szempontok alapján (pl. népességnagyság, magas eljárási arány, magas munkanélküliségi ráta) egyes településeket kiemelünk, és a két vizsgált mutató összefüggését nézzük, akkor is nulla körüli értékeket kapunk. A korrelációs értékek azt mutatják, hogy nincs kapcsolat a két mutató között. A hipotézis tehát országos méretekben nem helytálló, vagyis a telepưléseken a magas eljárási aránynak nem lett egyenes következménye a későbbi nagy munkanélküliség. (Ezt alátámasztják azok a kutatások, melyek kimutatták, hogy a településeken a munkanélküliek számának növekedésében jelentős szerepe volt a korábban inaktív keresők regisztrált munkanélkülinek való jelentkezése.) A fenti hipotézis kisebb, speciális területi egységek esetén lehet, hogy helytálló.

\section{A napi ingázás tere Magyarországon}

Az ingázási teret lehet horizontálisan (a földrajzi térben) és lehet vertikálisan (a településhierarchián belül) is értelmezni, valamint vizsgálat tárgyává tenni. Ebben az alfejezetben a horizontális szemléletmódot vesszük alapul.

$\mathrm{Az}$ ingázás a munkaerő naponta kétszeri telepưlésközi áramlása, ami a földrajzi térben, a településhálózaton belül zajlik. Az ingázás potenciális tere a teljes településhálózat, melyben a települések lehetnek munkaerőt kibocsátóak vagy/és befogadóak, az egyes közlekedési útvonalakon pedig áramolhat a munkaerö. Az ingázás valós tere ennek egy részhalmaza, melyet a munkaerót kibocsátó vagy/és befogadó települések, valamint a munkaerö-áramlás által igénybe vett közỉekedési útvonalak alkotnak. A részhalmaz kialakulásának oka, hogy nem garantált minden település és minden útvonal bekapcsolódása az ingázásba.

A gyakorlatban a két fogalom között szinte nincs különbség, mivel alig akad olyan település, amelyik ne kapcsolódna be az ingázásba (1990-ben mindössze egy ilyen település volt Magyarországon). Emiatt egyrészt az ingázó munkaerő nagyságrendi különbségei alapján érdemes az ingázási tereket lehatárolni, másrészt a fogalmak a települések oldaláról nyernek igazán értelmet (egy település szükebb-tágabb környezete az ingázás potenciális tere, a be- és eljáróik révén felfüzött települések halmaza pedig a valós tere).

Első közelítésben - a rendelkezésre álló adatok jellegéböl eredően - a nagytérségi jellemzök vizsgálhatók. Az 1996. évi mikrocenzus közöl megyei bontásban adatokat az ingázók arảnyáról, melyet érdemes összevetni az 1990. évi népszámlálás értékeivel (1. ábra).

A hagyományosan alacsony értékkel bíró Alföld (nagyfalvas, mezőgazdasági térség) nagyobb részén emelkedett, míg a volt ipari tengely mentén - ahol régóta jellemzó az ingázás - csökkent az ingázási arány (kivéve Komárom-Esztergom megyét). A közepes értékekkel bíró Dél-Dunántúlon és Szabolcs-Szatmár-Bereg megyében szintén csökkent az érték. Ki kell emelni Györ-Moson-Sopron, Vas és Komárom-Esztergom megye, valamint Budapest megemelkedett értékét. Ez utóbbiak esetén a lendulletes gazdasági fejlődés lehet a magyarázó tényezó (Budapest esetén a környezö telepưléseken végbement zöldmezős beruházások). Összességében az ábra egy kiegyenlítódési folyamatot tükröz. 


\section{1. ÁBRA}

A naponta ingázó aktiv kereső́k aránya megyénként 1990, 1996

(The Percentage of Active Earners Commuted Daily by Countie 1990, 1996)

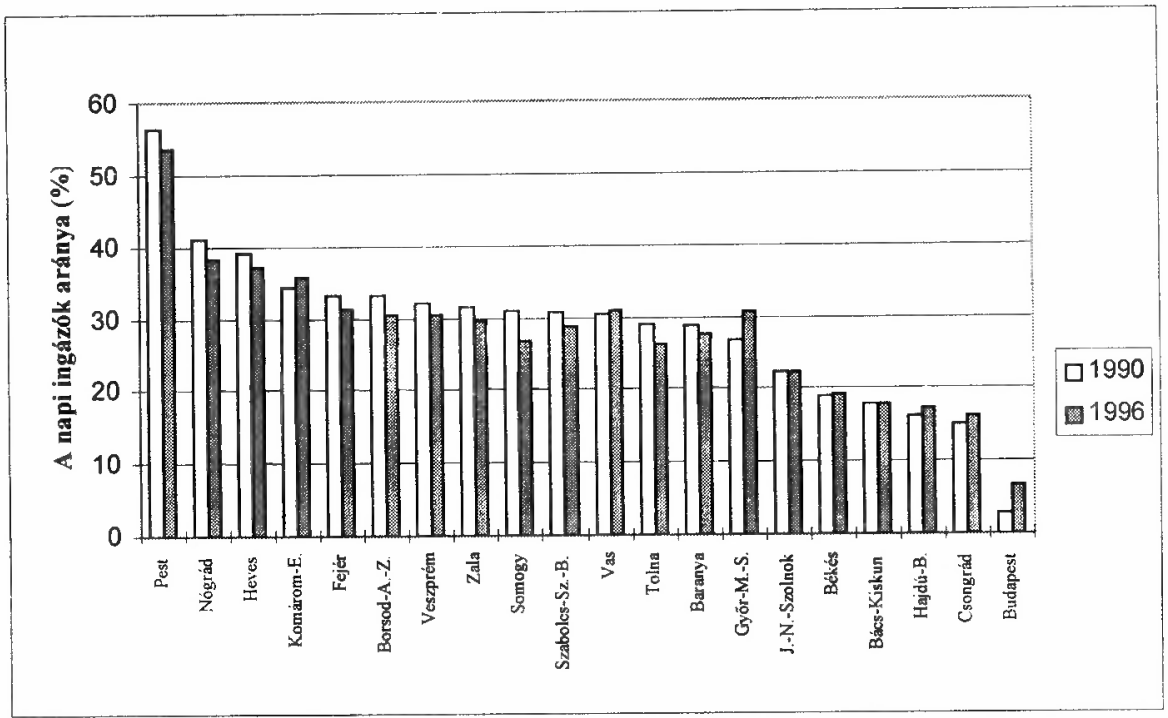

Forrás: KSH adatok alapján saját szerkesztés.

A térségi határoktól eltekintve az ingázás országos tere is felrajzolható. A településekre vonatkozó utolsó adatforrások (1990) alapján két értékhatárt figyelembe véve ( 373 fó - országos átlag, ill. 1000 fö) a 2. és a 3. ábra készült.

A 2. ábra alapján megállapítható, hogy Budapest és tágabb környezete volt az áramlások által leginkább összekapcsolt terület. Jelentős különbség figyelhetô meg a nagyfalvas Alföld és az aprófalvas Dél- és Nyugat-Dunántúl között. (A településeknél a lélekszám növekedésével általában nỏ a be- és/vagy eljárók száma.) Összefưggó áramlási zónák a Dunántúlon Budapesttől kiindulva nyugatra (Győr), délnyugatra (Székesfehérvár, Balaton ÉK-i része) és délre (Szekszárd, Pécs), nagyjából a föbb közlekedési útvonalak (közút és vasưt) mentén alakultak ki. Az Alföldön részben hasonló a helyzet (közlekedési útvonalak - Szolnok, Debrecen, illetve Kecskemét irányába), részben pedig foltszerủen jelentősebb székhelyek (például Debrecen) és környezetük voltak a jelentősebb munkaerő-áramlásba bekapcsolt területek. A központi góctól keletre a Budapest - Miskolc - Nyíregyháza - Záhony útvonal bonyolította le az ingázás jelentősebb részét.

Érdemes összevetni a térképet Schwertner János 1983-ban végzett közlekedésföldrajzi kutatásával, ahol a közlekedési szempontból peremhelyzetü települések elhelyezkedését vizsgálta. Az összefüggés jelentős területeken elég egyértelmü: a peremhelyzetü települések nem igazán tudtak bekapcsolódni a településközi munkaerőáramlásba. Ez alól a Dunántúl egyes részei, kifejezetten a Közép- és Észak-Dunántúl kivétel, ahol a jó közlekedési viszonyok mellett is alacsony volt az ingázók létszáma. Az áramlásból kimaradt területek településeire jellemzó, hogy 
gyakorlatilag az összes kis lélekszámú település (község) e típusba került (az összes 500 fö alatti település, valamint az 500 és 1000 fö közötti települések $98,5 \%$-a).

A munkaerővonzó települések 1990-ben az országban elég egyenletesen oszlottak el, hiányuk Borsod megye északi részén, Bács-Kiskun megye középső területén, valamint Budapesttől dél-keletre feltủnő. Kisebb vonzásközpont nélküli területek a Dunántúlon is vannak: Somogy megyében, Zala és Vas megye határán, valamint Györ-Moson-Sopron megye déli határvonala mellett. Érdekesek a több településböl álló munkaerỏt befogadó település-együttesek, melyek az Alföldön nagyobb számban voltak jelen 1990-ben (például Szeged - Hódmezővásárhely - Makó), mint a Dunántúlon (például Kapuvár - Csorna - Petőháza). A jelentősebb munkaerőt kibocsátó települések, mint várható volt legnagyobb számban Budapest környékén összpontosultak. Az Alföldön elöforduló nagyobb sủrüségük a terület nagy népességszámú községeinek volt köszönhető, míg az aprófalvas térségekben, föleg a Dunántúlon csekély volt a számuk. Ez utóbbi ténynek köszönhető, hogy több dunántúli munkaerót befogadó település körül nem, vagy csak egy-két jelentősebb munkaeröt kibocsátó település volt.

A 3. ábrán az 1000 fó feletti munkaerő ki- vagy/és beáramlásában érintett települések vannak feltüntetve, melyek a településkőzi munkaerö-áramlás legnagyobb koncentrációi, illetve az ingázás települési pólusai. A 2. és 3. ábrákat összehasonlitva megállapitható, hogy az ósszefüggó területek felszakadoztak, egyetlen komolyabb koncentráció maradt: Budapest és környéke, keleti és déli kiszögelésekkel. Kisebb összefügő területek Szeged, Békéscsaba, Debrecen, valamint Nyíregyháza körül helyezkednek el. Egy kivétellel a tengelyek is feldarabolódtak: a Budapest Cegléd - Szolnok vonal, mint fö áramlási csatorna maradt meg. Ezeken kívül kiemelhetó még például a Sajó-völgye vagy a Székesfehérvár - Dunaủjváros páros, ahol telepúléseket „sorosan” kapcsolt össze az ingázás. Érzékelhető a munkaerőt befogadó központok „Számbeli csökkenése”, de a határérték emelése a viszonylag egyenletes eloszláson nem sokat változtatott, mely leginkább a Dunántúlon szembetünö. A korábban megállapított befogadó központban hiányos területek közé - e csoportosítás szerint - mindössze az Észak-Alfơld és Dél-Nógrád került. A jelentős munkaerőt kibocsátó teleptulések 1990-ben nagy számban Budapest körzetében összpontosultak. (Az ország egyetlen komoly munkaerö-vonzási körzete.) Emellett kisebb mértékben a fentebb említett összefuiggő területeken, azaz a nagyvárosok környezetében voltak. Megemlíthető még, hogy jelentős számú munkaerőt befogadó, illetve kibocsátó telepuléspárosok jelentek meg az ingázási térben (pl. Tolna Szekszárd, Nagykőrös - Kecskemét, Vép - Szombathely stb.).

Az ilyen térképek gazdaságfơldrajzi információtartalma arra utal, hogy mely területek esnek ki a jelentősebb munkaerö-áramlásból, illetve mely térségeknek van szükségửk munkaeröt vonzó központra. Közlekedés-földrajzi információtartalma: mely területek lehetnek terheltek a nagyobb munkaerö-áramlás miatt, illetve mely térségekben okozhat gondot az alacsonyabb számú ingázó munkaerö (közlekedési eszközök kapacitásának ki nem használása vagy a több településen szétszóródott munkaerö „begyüjtése”). 


\section{2. ÁBRA}

Az ingázási mezö települési tagozódása 1990

(Settlement Division of Commuting Space 1990)

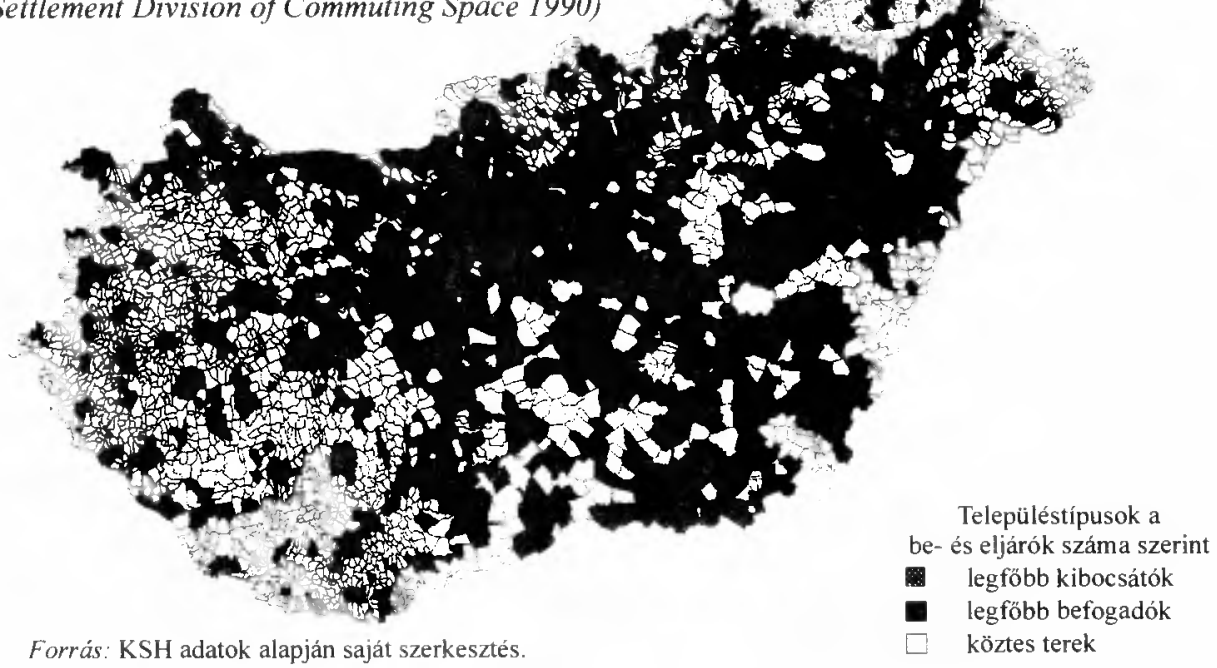

\section{3. ÁBRA}

Az ingázás települési pólusai 1990

(Settlement Poles of Commuting 1990)

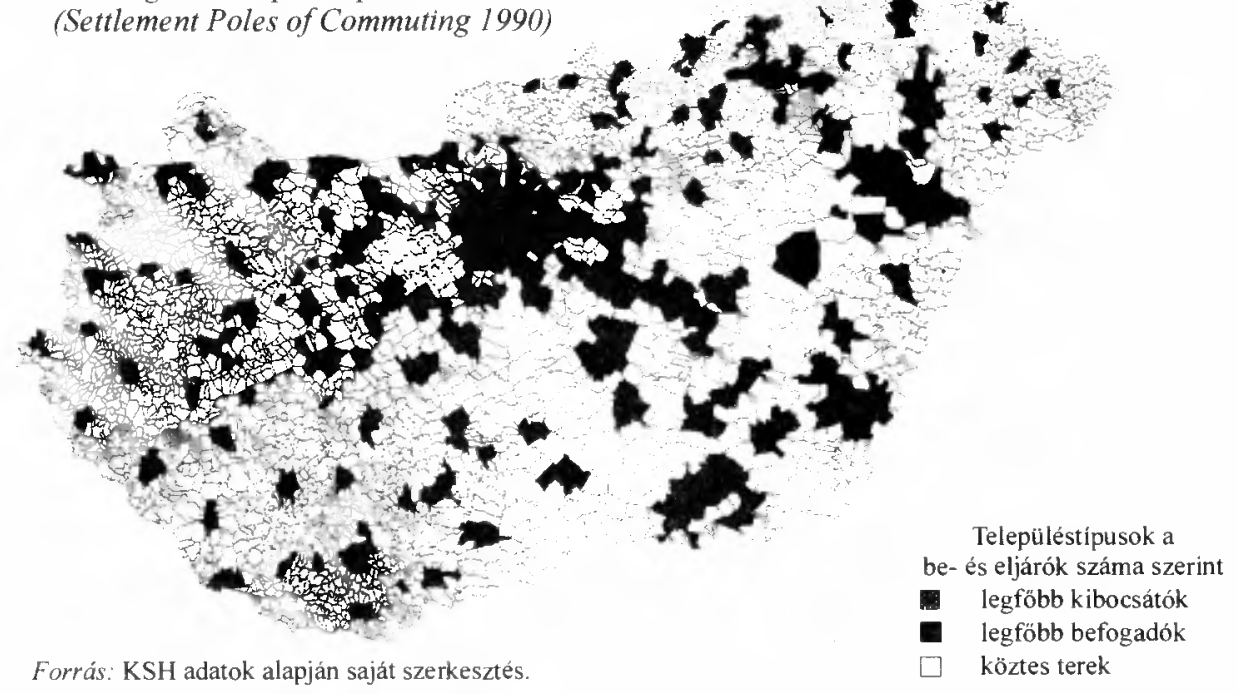




\section{A városi státus és a munkaerõvonzás kapcsolata}

$\mathrm{Az}$ ingázás vertikális terének vizsgálatakor visszatérö kérdés, hogy a városoknak funkciója-e a munkaerővonzás, vagyis munkahelyek biztositása a környezetében lévő települések lakói számára.

A probléma elöidézői voltak a magyar ingázási vizsgálatok során elöbukkanó munkahelyhiányos városok, valamint azok a nem városi jogállású települések (pl. bányászfalvak, nagyobb ipari üzemmel rendelkezỏ községek), melyek munkaerö-vonzási körzetet „alakítottak ki” maguk körül. Megszakadt egy - korábban egyértelmübbnek túnö - kapcsolat a városok és a községek között: a munkaerőt a községek kibocsátják, melyet a városok felszívnak. Ez abból a szempontból okozott (és okoz jelenleg is) gondot, hogy egy városi jogállással együtt jár-e a munkaerövonzás, illetve egy kőzség, ha munkaerővonzókẻnt jelentkezik, akkor városi státusra jogot formálhat-e. A jogállás és a szerepkör (vonzásközpont) fogalmak ellentéte alakult ki.

A téma tanulmányozása során az 1990-es adatokon teszteltem a kérdést, és igazolódott, hogy nem minden város töltött be munkaerővonzó szerepet. Az akkori 166 város köziil 45 esetén, azaz a városok valamivel több, mint egynegyedénél a munkaerő-kibocsátás volt a jellemzó. Ebböl 31 esetén egyértelműen ki lehetett mutatni, hogy egy vagy több közeli, általában nagyváros miatt alakult ki a munkaerö-taszítás.

Emellett kimutatható, hogy 28 község munkaerő-vonzás szempontjából megelözött 70 várost. Az 1990-ben jelentős munkaeróvonzással rendelkező kőzségek közul egyesek a gazdasági válságot túlélték (pl. Visonta, Bábolna, Balatonfüzfơ, Lábatlan), mások azonban elvesztették korábbi jelentőségưket (pl. Borsodnádasd, Környe, Mány). Egyre több község tesz szert - fơleg a külföldi befektetések révén munkaerö-vonzási funkcióra. Azonban egy-egy jelentősebb ủzem megléte még nem garancia arra, hogy a település várossá fejlődik, így remélhetỏleg a státusok megítélésénél egyrészt figyelembe fogják venni a vonzási funkciót, másrészt nem kap a jelentőségénél nagyobb hangsúlyt.

Az 1990 óta várossá nyilvánitott községek közül mindössze négy volt, mely a népszámlálás idöpontjában jelentősebb munkaerővonzást gyakorolt a környezetére: Bóly, Héviz, Devecser, Baktalórántháza. (Közülük az utóbbi kettő később jelentős munkanélküliséggel sújtott településsé vált.) A többi új város kőzött az elmúlt idöszakban nem sok válhatott jelentősebb munkaerővonzóvá, mivel többségüknél magas munkanélküliség lépett fel (több mint kétharmaduknál a munkanélküliség tetözésekor [1993-ban] 10\% felett volt a munkanélküliségi ráta). Az új városok többsége ennek eredményeképpen gyengítette a funkció városi jellegét, vagyis ha lennének aktuális adatok az ingázásra, akkor a vizsgálatok feltehetöleg kimutatnák, hogy a jelenlegi városok jelentős része (akár $35-40 \%$-a is) nem fejt ki számottevô munkaerővonzást. (E hipotézis igazolására csak a következỏ népszámlálás adatainak ismeretében lesz lehetőség.) Az a tény, hogy a városi jogállás megszerzése idővel a kör- 
nyező terület számára nyújtható szolgáltatások fejlődését (köztük munkahelyek biztosítását) eredményezheti, ez inkább az elmúlt rendszerben, a tervutasításos gazdaságban valósult meg.

Összefoglalóan a kérdéssel kapcsolatban megállapítható, hogy a probléma - városi funkció-e a munkaerővonzás - éló. Véleményünk szerint egy település attól város, hogy több funkciója révén környezetét kiszolgálja, melyek között általában előfordul a munkaerővonzás. Ha nem funkcionál a munkaerővonzás, de a többi viszont igen, akkor a városi státus nem igazán kérdöjelezhetö meg. Azonban ha egy település gyakorlatilag nem szolgálja ki környezetét, akkor nem tekinthető városnak, még ha annak is nyilvánították. A községek közül azok, melyek jelentős munkaerővonzóként lépnek fel figyelmet érdemelnek, mivel e funkció mellett esetleg mások is megjelenhetnek (a munkaerő ingázása más célból is igénybe vehető áramlási csatornákat hoz létre), de a munkaerővonzás még nem elegendő funkció.

Emellett nem elhanyagolandó tényezö - többek között - a munkaerővonzás egyegy település jogállásának megváltoztatásakor. A környező települések lakói számára - ha igény van rá - a munkahely lényegesebb, mint pl. a városi kép megléte. Ez Magyarországon jelenleg azért aktuális, mivel jobban korlátozni kellene a várossá nyilvánítás kritériumait, hogy fékezzük országunkban a városok indokolatlan elszaporodását. Ennek kiváló eszköze lehet egy munkaerő-vonzási kritérium beépítése, hiszen ezzel egy súlyos probléma, a munkanélküliség is érintve lenne. Érdekeltté válnának a városi státusra igényt tartó települések abban, hogy munkahelyeket teremtsenek a környező, korábban elhanyagolt községek - több esetben munkanélküli - aktív keresőinek foglalkoztatása céljából.

\section{A napi ingázást érintő társadalmi, gazdasági folyamatok}

Magyarországon a foglalkozási átrétegződés még nem ment teljesen végbe: a mezógazdaságban dolgozók aránya magasabb, a tercier szektorban dolgozóké pedig alacsonyabb, mint az EU több országában. A mezőgazdaságból más szektorokba történő átáramlás kis mértékben és nem látványosan, de jelenleg is zajlik. A gazdaság fejlődésével a folyamat felgyorsulhat, föleg az EU-hoz történő csatlakozás után. Ekkor a mezőgazdasági termelés különböző megszorításai miatt feltehetőleg jelentős számú termelő fogja feladni veszteségessé váló gazdaságát, és más ágazatban keres majd munkát. Közülük sokan az ingázók számát fogják gyarapítani.

Magyarországon az elmúlt években jelentősen átalakult az ipar ágazati és területi szerkezete. Az ipar területi átrendeződését, a gazdasági súlypont nyugatra tolódását egyenlöre nem követte a munkaerö részleges átcsoportosulása (miközben magas munkanélküliség jellemzó keleten, addig egyes helyeken már munkaerőhiány lépett fel nyugaton). A korábban preferált ipari zónákban „megrekedt” munkaerő nem képes elmozdulni, mivel jelentős szakadék van a jelenleg prosperáló, és a depresszió sújtotta térségek ingatlanárai között. Egy részük a lakóhelyhez való ragaszkodás miatt nem is kíván elvándorolni. A munka- és lakóhely közötti területi diffe- 
renciák feloldását jelentené a napi ingázás, mely azonban a nagy távolságból eredően nem képes jelentös mértékben enyhíteni a feszültséget. (A heti ingázás rendszere megszünt, és úgy tủnik a közeljövőben sem fog újjáéledni.)

A tercier szektor előretörése kedvez a gazdaság egyenletesebb térbeli szerveződésének. Ez elönyös abból a szempontból is, hogy emelkedhet az egyes településeken belül a munkahelyek száma, $s$ így csökkenhet az ingázók aránya is.

A közlekedés fejlődése az ingázás nagyságát eìvileg növelheti. A közutak terheltek, a hatvanas évek forgalmára méretezettek. Épültek új autópályák, melyek használatárt fizetni kell, és a többinél is tervezik a dij bevezetését. E tényezök nem kedveznek a személygépjármüvel való ingázásnak. A távolsági tömegközlekedés helyzete nem sokat változott az elmúlt időszakban. Egyes vonalakon - mind vasút, mind buszközlekedés - ritkították a járatokat, söt egyes helyeken meg is szüntették. A távlati célok között nem szerepel ennek az ágazatnak a preferálása, így a közlekedés-földrajzi szempontból elzárt települések továbbra sem tudnak bekapcsolódni az ország vérkeringésébe. A magas uzemanyagárak, valamint a távolsági közlekedés folyamatosan emelkedö tarifái erős gátló tényezőként lépnek fel az aktiv munkaerő jelentős részénél, mikor munkahelyet keresnek. Ezek a tényezők szintén gátolják a napi ingázást.

Magyarországon jelenleg kiemelt probléma a munkanélküliség, melynek oka a gazdaság megroppanása volt. A gazdasági élet jelenlegi újjáéledése a korábbi területi szerkezetet nem veszi figyelembe, így - többek között - nem kötödik a mennyiségi munkaerőhöz. Ennek eredményeként a korábban munkaerövel telítödött térségekben a munkanélküliség csak kismértékben csökkent. Az ingázás feladata lenne, hogy a térbeli differenciáltságból eredö feszültséget csökkentse, de ezt a fentebb vázolt tényezök miatt nem képes végrehajtani. A munkahelyek jelentös része térben eltávolodott a munkaerỏtől, míg a közeliek pedig a magas utazási költségekböl eredően lettek ,távoliak".

Kutatási eredmények támasztják alá, hogy ,a kiterjedt napi ingázás jelentékeny mértékben csökkenthetné a regionális egyenlötlenségeket, sőt - mivel a közlekedéssel összekapcsolt nagyobb piacokon kisebb a súrlódás, mint az elkülönült részpiacokon átlagosan - akár a munkanélküliség szintjét is" (Köllö 1997, 33). Amennyiben a közlekedési költségek általánosan és jelentös mértékben változnának (pl. bevezetnének valamilyen utazási támogatást), akkor átrendezödnének a regionális piacok határai. (A közlekedési költségek emelkedése szükebbre vonhatta, a személygépjármü-állomány óriási növekedése viszont kitágíthatta a régiók határait.) A tömegközlekedési kapcsolatok erősebben befolyásolhatják a munkaerö-piaci egyenlőtlenségeket, mint a személygépjármüvek, a viszonylag sürủ városhálózat és a szerény távolságok ellenére vonattal vagy autóbusszal kevés központ érhető el, és a vonalak szakadozottsága miatt a városok elérésének átlagos költsége magas. A jelentős munkanélküliség sújtotta települések nagyobbik részénél a helyi közlekedés javítása hozzájárulna a munkanélküliség csökkentéséhez (Köllő 1997). 
Említettük, hogy számos külfơldi cég létesített Magyarországon új üzemeket, melyek területi elhelyezkedésüket nézve nagyobbrészt Budapest tágabb környezetében, valamint Észak- és Nyugat-Dunántúl térségében találhatók. Ezeknél a vállalatoknál jelentósebb számban foglalkoztatnak nemcsak helyi munkaeröt, hanem a környezö települések munkaerejét is (akár a falvak fizikai munkaerejét, akár a városok szellemi munkaerejét), akik az ingázók számát gyarapítják. Egy régi jelenség megújulását tapasztalhatjuk abban, hogy több nagyvállalatnál meg is szervezik a dolgozók szállítását (pl. Győrött, Székesfehérváron). Megemlítendö, hogy egyre több ipari park nyílik az országban, ahol a munkahelyek nagyfokú térbeli koncentrációja jön létre. Ezeken a munkaerőgyüjtő telephelyeken jelentősebb számú ingázó is jelen van.

$\mathrm{Az}$ ingázók számának alakulására jelentősen hatást gyakorolnak az egyre több nagyváros körül kialakuló agglomerációs zónák. A népesség szuburbanizációját egyenlöre nem mindenhol követi a munkahelyek szuburbanizációja, így a központi településre irányuló munkaerő-beáramlást növelik a kiköltözők. Érdekes ellenáramlások is kialakulnak, mivel a nagyvárosok (kifejezetten Budapest) környezetében elhelyezkedő egyes településeken ipari üzemeket, jelentősebb bevásárlóközpontokat is létesítenek, melyek részben a nagyváros munkaerejére támaszkodnak (nem mindig elegendő mennyiségü vagy minőségü a helyi munkaerő). A népesség szuburbanizációja és a munkahelyek városkörnyékeken való megjelenése aktuálisan ható tényezők, melyek együttes jelentkezése esetén, ha a munkaerö-kereslet és kínálat nem találkozik, akkor az ingázás mértékét növelik (például Budaörs esetén az eljárók közel fele Budapestre jár, míg a bejárók majdnem mind Budapeströl érkeznek), ha találkozik, akkor az ingázás mértékét csőkkentik.

Az ingázással kapcsolatban kiemelhető még, hogy megváltoztak és változni fognak egyes jellemzői. Például a „blokkolós” gazdasággal ellentétben jelenleg a rugalmas munkaidő kezd elterjedni, emiatt a klasszikus munkaerö-áramlási időintervallumok kitágultak. Ezentúl növekvö tendenciát mutat a nem egy ponthoz kőthetö munkahelyek, állások száma (az 1996. évi mikrocenzus kimutatta, hogy a korábbi felmérésekhez képest a munkavállalók jelentősebb aránya jelöli meg a „munkahely változó" kategóriát). Megnőtt a munkavégzés során bekövetkező térbeli mozgások aránya is. Ebben az értelemben az ingázás vesztett a jelentőségéböl, mivel csökkent azon munkavállalók aránya, akiknek a munkába járás és a hazautazás komoly tényezöként szerepel a napi programjában, azaz a munkavégzés közbeni mobilitás mellett egyes aktív keresőknél fel se tünik a lakó- és munkahely közötti ingázás (pl. a vállalkozók egyre gyarapodó rétegéből sokan nem a munkahelyükön ülnek, hanem nyersanyagért, áruért stb. járnak). Ezen kívül léteznek olyan szakmák, melyeknél a munkába járás nem két fix pont közötti távolság megtételét jelenti.

Az ingázás jövőjét illetően még egy tényezőről szólni kell. A fejlett országokban egyre nagyobb teret hódít az ingázás csökkenését elöidézỏ ún. telemunka. A telemunka az új információs-kommunikációs technológiák segítségével a felhasználótól távoli otthonról vagy más „decentrált" fekvésủ munkahelyről végzett 
elektronikus munka („távmunka”). Előnye a munkavállaló számára, ha otthonában tud dolgozni, hogy többek között nincs szükség a munka- és lakóhely közötti távolság áthidalására, ha lakóhelyére telepített munkahelyközpontban tud dolgozni, akkor pedig nincs szükség a településközi távolság leküzdésére, vagyis függetlenedik a munka a távolságtól, így a településtől, a településhatároktól is. Az egyén munkaeröpiaci lehetőségei ezzel jelentősen megnőnek. A közlekedés kiiktatódik a rendszerből, így ennek káros hatásai is megszünnek. Az ingázás fogalma részlegesen értelmét veszti (a munkavállaló helyett az információk ingáznak az illetó lakóhelye és munkaadójának települése között). A munkaadó számára többek között előnyt jelent, hogy az utazási hozzájárulást megtakarítja, valamint elzárt munkaerópiacokat tud feltárni, így mobilizálni tudja az elfekvő munkaerő-potenciált. Megfordul a szituáció, $\mathrm{s}$ vele együtt a problémák: nem az embereket kell a munkahelyre vinni, hanem az emberek munkáját kell immateriális módon (az elektronikus távközlés segítségével) elszállítani (Erdösi 1992). Hazánkban is kezd elterjedni a telemunka, a munkanélküliség csökkentésének egyik eszközét látják benne. Aktualitása nö, az elsố komolyabb kísérletek e téren jelenleg zajlanak.

\section{Az egyes részpolitikák hatása a napi ingázásra}

$\mathrm{Az}$ ingázásra, s ezáltal az ingázók számára hatással van számos részpolitika. A gazdaságpolitika a munkahelyek térbeli szóródását, illetve koncentrálódását idézheti elö. Az utóbbi az ingázás csökkenésének irányában hat, az elöbbi inkább ellene. A munkahelyteremtés egy-egy település esetén kétféle módon befolyásolhatja az ingázást, egyrészt csökkenhet az eljárók száma, másrészt növekedhet a bejárók száma. A lakáspolitika a lakóhelyek térbeli elhelyezkedésére van hatással, s ezen keresztuil az ingázást is érinti. Új lakóházak épitésének vagy a lakásbérleti rendszernek a támogatása, az ingatlanárak területi differenciáinak közvetett mérséklése csökkentheti az ingázás nagyságát (a munkahely telepưlésére költözés). E tényezők révén az ideiglenes migrációban résztvevơk, az ingázók tényleges elvándorlókká válhatnak. A közlekedéspolitika, a közlekedés-fejlesztés jelentös hatással van az ingázásra: a településközi munkaerő-áramlás csatornáinak biztositása (gyors megközelíthetőség, korszerủ és sủrủ tömegközlekedés stb.) alapvető az ingázás szempontjából. A közlekedési tárca által preferált, s így fejlesztett területeken az ingázás növekedhet, míg az elzárt térségek kimaradnak a munkaeró-áramlásból. A munkaerö-politika (humán eröforrások) szintén hatással lehet az ingázásra. Ha támogatják - föleg a munkanélkuliség csökkentése érdekében - a más települések munkaerejének foglalkoztatását (utazási költségekhez való hozzájárulás), akkor az ingázás növekedését idézhetik eló.

A területfejlesztés feladata a természeti, társadalmi és gazdasági tényezök területi harmóniájának a megteremtése. Alapvető cél a munka- és lakóhelyek területi egyenlősége. Ennek érdekében a munkanélküliség sújtotta területeken a munkahelyteremtés szükséges, míg a munkaerö-hiányos területeken a lakóhelyteremtés. A 
kettő települési szinten történő bizonyos fokú összehangolása már inkább a településfejlesztés feladatköre. A helyes területi politika a kiegyenlítésre törekszik, vagyis nem cél se a munkahelyek, se a lakóhelyek drasztikus átcsoportosítása térségi szinten. (Kiemelendö, hogy a munkahelyeket kell közelíteni a lakóhelyekhez.) Ha nem sikerül a területi differenciák csökkentése, akkor a lakó- és munkahely (azok települései) közötti kapcsolat - a munkaerő-áramlási csatornák - biztositása a feladat. Ez a napi ingázásnál leginkább a kistérségi szinten jelentkezik, mivel a korlátozott utazási időtartam dominanciája érvényesül. Vagyis a közlekedési kapcsolatok javítása enyhítheti a területi differenciákból származó feszültségek feloldását. Magyarországon sajnos ezek a differenciák jóval nagyobbak (lsd. kelet-nyugat ellentét), mintsem a napi ingázás megoldaná óket, de mint fentebb Köllö J. is kimutatta egyes területeken részleges megoidás lenne a problémára (Köllö 1997). (Vannak olyan kistérségek, ahol enyhíthetőek lennének a feszültségek.)

Magyarországon a gazdaságpolitika helyesen törekszik a munkahely-teremtésre a munkanélküliség sújtotta térségekben. A lakáspolitika irányvonala azonban megkérdőjelezhetö. Egy országban, ha nincs nagy különbség a gazdasági régiók fejlettsége között, akkor az ingatlanárak területi differenciái kicsik. Természetes, hogy Magyarországon nem lehetséges és nem is szükséges a területenként eltérő ingatlanárak nagyfokú közelitése, mivel a gazdasági fejlettség ezt nem indokolja. A népesség közel egyenletes eloszlása a kedvezö, így pozitív megítélésü, hogy az ingatlanárak „fékezik” a nagyfokủ belsỏ migrációt. Nem ürülhet ki egy Borsod-Abaúj-Zemplén megye a gazdasági depresszió miatt, és nem telítődhet egy Győr-Moson-Sopron megye a kedvező pozíciója miatt. Azonban az árak közötti szakadék idővel problémát okozhat, mihelyt munkaeröhiány lép fel Nyugat-Magyarországon. Sajnos a befektetők többsége külföldi, így nem garantált, hogy a nyugati országrész telítődése után a keleti régiókban fognak befektetést eszközölni (habár a legújabb megfigyelések azt mutatják, hogy nő az esély rá), inkább más országban keresnek telephelyet. Indokoltnak tünik az ingatlanárak bizonyos fokú közelítése, annak érdekében, hogy a keleten megkötőtt munkaerő egy része a jobban prosperáló térségekbe tudjon áramolni, mely a jelentősebb népsủrüségi differenciák kialakulásáig elfogadható. Igaz, hogy a gazdasági tényezők jelenleg jóval erösebben hatnak, mint más tényezők, de ennek a problémának a boncolgatását szociológiai oldalról is meg kellene tenni: vajon a lakóhelyhicz való rạgaszžkodás jelenleg mennyire erös a társadalomban, mekkora szerepe van az eltéró mikro- és mezokultúráknak, vagy a beilleszkedési nehézségeknek az esetleges migrációs lehetőségeknél. Vagyis mennyiben változott meg a társadalom migrációs kultúrája, azaz hajlandóak-e az emberek egy munkahely miatt elköltözni más településre.

Ez a kérdéskör azért is córdemel több figyelmet, mivel a különböző közvetett gazdasági, jogi eszközök gyakran nem elegendőek arra, hogy a gazdasági sürüség egyenletes mértékét elérjük (lsd. kelet-nyugat ellentét). A multinacionális vállalatok döntéseit nehéz befolyásolni, így érdemes előregondolkodni. Egy prosperáló térségben a nagyarányú beruházások esetén idővel munkaerőhiány léphet fel, melyet lehet, 
hogy a környezete (ingázás) sem képes már kielégíteni. Ilyenkor a betelepítési politikák (akár kormányzati, akár önkormányzati oldalról) kerülnek majd előtérbe, melyekre nem árt elöre felkészuilni. Ugyanakkor azt sem szabad elfelejteni, hogy elég sok külföldi vállalat mobil, azaz idővel lehet, hogy máshová teszi át telephelyét. A munkaerő egy részére ilyenkor - ha addig a helyi gazdaság nem erősödött meg kellôképpen - ismét lakóhelyváltás vár. (Nem szabad a multinacionális vállalatok által eszközölt beruházások mindenhatóságában bízni, ki kell mellette épülni egy erős, a változásokra rugalmasan reagálni képes lokális szerveződésủ gazdaságnak is.)

A közlekedéspolitikában inkább a makroszintü feladatokon van a hangsúly: a nagytérségi kapcsolatok kiépítésén (pl. a déli autópálya), és az európai úthálózatba való bekapcsolódáson (pl. a Balkán és Nyugat-Európa autópályával való összekapcsolása). A mezo- és mikroszint közlekedési problémáinak megoldása a jövő távlati céijai között szerepel, így az ingázás közlekedési feltételeinek javulása nem várható a közeljövőben. Kifejezetten hátrányos lenne, ha az állami kézböl kikerülnének a tömegközlekedési vállalatok, mivel profitorientáltságuk miatt több térségben jelenleg is megritkított közlekedési kapcsolatokat tovább csökkentenék. (Felszámolnák a veszteséges vonalakat, járatokat.)

A munkaerö-politika igyekszik - föleg a munkanélküliség csökkentése érdekében - az ingázást szerény eszközökkel támogatni. 78/1993. évi Kormányrendelet mondja ki, hogy minden munkáltató köteles költségtérítési hozzájárulást fizetni a munkavállalónak (az utazási költség 86\%-át vasút 2. osztály, 80\%-át elóvárosi vasút és helyi, valamint távolsági autóbusz esetén, és egyes esetekben üzemanyag hozzájárulást kell fizetni a személygépkocsi használatánál is). Ez a rendelet áthárítja a költségek jelentős részét a munkaadóra (leveszi a teher egy részét az ingázók válláról), akinek azonban így nem igazán érdeke ingázók foglalkoztatása. (Munkaerőbőség esetén elöfordulhat, hogy a rendeletet nem tartják be.) Csökkentik az ingázásra is kész aktív keresők anyagi terheit, de egyúttal esélyeit is a munkavállalásra. A 39/1998. évi Kormányrendelet a munkába járással összefüggó terhek csökkentését célzó támogatásokról is szól. A rendelet alapvető célja, hogy a munkanélkưliséget csökkentse: a munkaadó számára egészben vagy részben megtéríthetővé teszi az újonnan alkalmazott dolgozóinak munkába járással kapcsolatos utazási költségeihez való kötelezö hozzájárulást, ha hosszabb ideje nyilvántartott munkanélkülit alkalmaz, és ha hasonló munkakörben foglalkoztatott munkavállaló viszonyát nem szüntette meg a közelmúltban. A csoportos személyszállítást (saját vagy bérelt autóbusszal, személygépkocsival) bizonyos feltételek mellett szintén támogathatóvá teszi (pl. abban az esetben, ha az oda- és visszautazás időtartama tömegközlekedési eszközzel a két órát meghaladja).

A területfejlesztésben az elmúlt évtizedben nagyobb figyelem irányult az ingázásra, mint jelenleg. A terület- és településfejlesztés hosszú távú feladatai (Országos Tervhivatal, Épitésügyi és Városfejlesztési Minisztérium 1985) címü, az Országgyúlés 12/1980-85. számú határozatának háttéranyagául szolgáló munkában is 
találkozunk a jelenség vizsgálatával. A munka szerzői rámutatnak, hogy a korábbi években a területileg arányos iparosítás révén sikerült mérsékelni a távolsági ingázást, de a közlekedési hálózatok elmaradt felújitása miatt feszültségek keletkeztek a napi ingázás terén. A gyors ütemü motorizáció viszont javította az ingázás feltételeit. Célul tủzték ki, hogy a szociális- és a létbiztonság megőrzése érdekében folyamatosan meg kell teremteni a teljes és hatékony foglalkoztatás területi feltételeit, melynek kapcsán törekedni kell a távolsági ingázás további mérséklésére, oly módon, hogy elő kell segíteni a munkaerő és az eszközök területi mobilitását (a munkahelyek és lakóhelyek közelítését). Az ipar területi decentralizálásában látták az eszközt a nehezen mozgósitható munkaerő bevonására. A közlekedésfejlesztésnél cél volt, hogy a belső elvándorlás lefékezése érdekében javítani kell a napi ingázás feltételeit (tömegkőzlekedés színvonalának emelése). Munkaerő-politikai célként a munkaerö-felesleggel még korlátozottan rendelkezö területeken a foglalkoztatás elősegítését jelölték meg.

Az 1997. évi Országos Területfejlesztési Koncepcióban nem kapott nagy hangsúlyt a kérdés. A társadalmi problémák területi vetületeinél egy mondatban megemlítik, hogy a foglalkoztatás csökkenése nemcsak a munkahelyek településein fejtette ki hatását, hanem az egész ingázási övezetben. A koncepció irányelvei között az ágazati politikákban közvetve jelenik meg az ingázás kérdésköre. A lakáspolitikával foglalkozó résznél célul tủzik ki, hogy mérséklődjenek a lakásállomány területi elhelyezkedése és jellege, valamint a lakossági igények közötti ellentmondások, különös figyelmet forditva az építkezések és felújitások területi megoszlására. A gazdaságpolitikai célkitüzéseknél a kedvezőtlen helyzetủ térségekben a beruházások arányának növekedését célzó közvetett támogatások preferálása kiemelhetö. Az ipar térbeli szerkezeténél megállapítják, hogy az ipari fejlettség területi különbségei a korábbi kiegyenlítődési tendenciát megtörve ismét jelentősen növekedtek, a külföldi befektetések térben nagyon koncentráltan helyezkednek el. A célkitüzések között szerepel az ipar hatékonyabbá tétele, és térbeli aránytalanságainak csökkentése. A legfőbb közlekedéspolitikai célként egyértelműen az európai hálózathoz való csatlakozást jelölik meg. Kiemelik, hogy a társadalom egyes rétegei számára a tömegkőzlekedés továbbra is alapellátásnak minősül, ezért tovább kell javítani a tömegközlekedés minőségét és szinvonalát. A fejlesztési javaslatok túlnyomó részében az európal verkerıngésbe való bekapcsolódást irányozzák elö, kisebb részben a régiók kőzötti kapcsolatok kiépítését szorgalmazzák.

A területfejlesztés térségi dimenziójánál a koncepció szerzői megjelölték a beavatkozási térségtípusokat. Az ipari szerkezetváltás által érintett térségeknél röviden szólnak az ingázásról: „A nagyarányú ipari visszaesés területi differenciálódását növelte egyrészt az, hogy egyes iparágak a kedvezőbb adottságú és dinamikus térségekbe települtek, másrészt - és ez a fỏ ok - a válságba került ágazatok jelentős hányadban ingázó, más térségben lakó, esetenként külföldi munkaerőt foglalkoztattak. A válság és a munkanélküliség terhei ezért egymástól eltérö helyen jelentkeznek." (Országos Területfejlesztési Koncepció 1997, 80) A tartós, jelentős munka- 
nélküliséggel küzdö térségeknél már több figyelmet szenteltek a kérdésnek: „...Számos térségben a munkanélküliség fö oka ... az ingázás lehetöségeinek beszükülése, költségeinek megnövekedése, és ezáltal az adott térségben lakó, de máshol dolgozó keresök munkahelyének elvesztése. A tartós munkanélküliség, az ingázási lehetőségek csökkenése nem szükebb térségekhez kötődő jelenség, az e probléma kezelésére felhasználandó eszközök nem korlátozandók meghatározott térségekre. A koncentráció elvének megfelelöen, azonban néhány térségben a közlekedési lehetöségek javításához, munkahelyek teremtéséhez, a képzés, átképzés intézményes megoldásához, valamint a helyben nyilvánvalóan megoldhatatlan gondok esetében az áttelepülés, a térbeli mobilitás elösegítéséhez összehangolt beavatkozásra van szükség." (Országos Területfejlesztési Koncepció 1997, 82)

A településhálózat fö alkotó elemeinek fejlesztési irányai között a közepes és nagy községèk címszó alatt foglalkoznak még röviden a problémával: „A mezőgazdaság mai súlyát és munkaeröigényét figyelembe véve a közepes és nagyobb községek népessége kizárólag mezögazdaságból nem tud megélni. Egyik megoldás továbbra is az ingázás, ennek lehetőségei azonban az utóbbi időben beszükültek, költségei megnövekedtek. Ugyanakkor már elég jelentős munkaeröforrást és piacot biztosithatnak a helyben müködỏ vállalkozások létrehozására. Figyelembe véve, hogy a szakképzett és betanított munkásságnak legnagyobb hányada e településeken él, ez komoly fejlödési potenciált jelent." (Országos Területfejlesztési Koncepció 1997, 115)

Összefoglalva az ingázás kérdésköre kisebb hangsúlyt kap a koncepcióban. A munkanélküliség problémájának kezelésében a lokális munkahelyteremtés az eröltetett irányvonal, mellette szerényebb jelentőséget tulajdonítanak az áttelepülés elösegítésének, illetve a közlekedési lehetőségek javításának, s így az ingázás kedvezőbb feltételeinek megteremtésének.

A fentiek is alátámasztják azt a megfigyelést, hogy az ingázás kérdésköre az aktuális politikában is háttérbe szorult. Nem került a közlekedésfejlesztés prioritásai közé a településközi úthálózatok, így a települések kőzötti kapcsolatok javítása, és nem túl intenzíven támogatják a munkahelyek székhelyétől eltérő telepuléseken lakók foglalkoztatását sem. Úgy tủnik, nem látnak ebben komolyabb perspektívát a munkanélküliség csökkentésére sem. Mindezek annak ellenére fennálinakak, hogy az aktív keresők közel egynegyede ingázó és a munkanélkưliség sem megoldott probléma. Ezen a téren bekövetkezỏ változásokat csak remélni lehet.

\section{Zárszó}

A napi ingázás aktuális része a kơvetkezö népszámlálásig nehezen, illetve közvetett eszközökkel kutatható, de nem érdemli meg azt a nagyfokú mellözöttséget, melyben jelenleg része van. Nem szabad elfelejteni azt a tényt sem, hogy az EU-hoz való csatlakozás után feltehetőleg megindul a munkaerỏ országhatárt átlépő ingázása is (mint új téma terítékre fog kerülni). Ez bekövetkezhet mindannak ellenére, hogy lassan átlépünk a XXI. századba ahol, mint Erdősi Ferenc megfogalmazta, 
nem az embereket kell majd a munkahelyre vinni, hanem az emberek munkáját kell immateriális módon (az elektronikus távközlés segitségével) a lakóhelyekről elszállítani.

\section{Irodalom}

Böhm A.-Pál L. (1985) Társadalmunk ingázói-az ingázók társadalma. Budapest, Kossuth Kiadó.

Erdősi F. (1992) Telematika. Budapest, Távkőlési Könyvkiadó.

Hunya G. (1981) Napi ingázás Magyarországon. - Földrajzi Közlöny 2. 128-139. o.

Illés S. (1995) A teruleti mobilitás volumenének változásai. - Statisztikai Szemle. 7. 543-555, o.

Iván L. (1994) Módszertani gondolatok az ingavándor-forgalom kutatásához. Mühely. 1.

Kapitány G. (szerk.) (1994) 1990. évi népszámlálás, 39. kötet: Az aktív keresök munkahelye és lakóhelye (Ingázási adatok). Budapest, Kozponti Statisztikai Hivatal.

Kapitány G.-Lakatos M. (1993) A munkaerö napi mozgása Budapesten és a fövárosi agglomerációban, 1970-1990. - Statisztikai Szemle. 8-9. 651-685. o.

Klinger A. (föszerk.) (1996) Demográfia. Budapest, Központi Statisztikai Hivatal.

Kollö J. (1997) A napi ingázás feltételei és a helyi munkanélkuliség Magyarországon. - Fsély 2. 33-61. o. Mikrocenzus 1996, A foglalkoztatottság alakulása 1980-1996. (1997) Budapest, Kozponti Statisztikai Hivatal.

Nemes Nagy J. (1998) A tér a társadalomkutatásban. Budapest, Hilscher Rezső Szociálpolitikai Egyesulet.

Országos Területfejlesztési Koncepció. (1997) (munkaanyag) Budapest, Környezetvédelmi és Területfejlesztési Minisztérium.

A terület-és településfejlesztés hosszú távú feladatai. (1985) Budapest, Országos Tervhivatal.

Útkeresés és szociális biztonság (Elgondolások az átmeneti idôszak szociálpolitikájáról), Statisztikai melléklet. (1989) Budapest, Kozzponti Statisztikai Hivatal.

1960. évi népszámlálás 9. kötet: A kereső́k munkahelye és lakóhelye, A népesség 1949. és 1960 évi lakóhelye. (1963) Budapest, Kozponti Statisztikai Hivatal.

1970. évi népszámlálás: Az aktiv keresōk munkahelye és lakóhelye (A napi ingázók adatai). (1976) (munkaanyag) Budapest, Kozponti Statisztikai Hivatal.

1980. évi népszámlálás 33. kötet: Az aktív keresök munkahelye és lakóhelye (A naponta ingázók adatai). (1983) Budapest, Kozzponti Statisztikai Hivatal.

\section{THE QUESTIONS OF THE COMMUTING IN THE NINETIES IN HUNGARY}

\section{PÁL SZABÓ}

In the nineties the idea of the commuting is disappearing from the mind of the hungarian society. The examination of its attributes is a rare topic in scientific researches and it falls into the background in the interest of sectorial politics nowadays in Hungary. These facts are causeless because the newest data (1996) shows that 25 per cent of occupied population is commuter just as in 1990 .

The statistical definition of commuting is criticized sometimes, but it is widely conceded with some mistakes, so the arising opinions do not cause serious dilemmas.

In the formation of commuting objective and subjective factors participate, but during the historical development most of them altered. 
The earlier growth tendency has changed since 1980 in Hungary: the number of occupied population and of the commuters decreased. In spite of this decrease the rate of the commuters grew between 1980 and 1990, and the index has stagnated since 1990. The explanation of it is a collective effect of more social and economical factors.

It is an interesting fact that the high rate of commuting does not cause high rate of unemployment in most of settlements. It is interesting also that the contact of the city status and the attraction of labour weakened in the previous years. These are reinforced by statistical datas.

In nineties a lot of new social and economical factors affect the commuting in Hungary. In addition to the decisions of sectorial politics affect the commuting too. These are collected in the second part of this study. 